\title{
THE EFFECTIVENESS TO USE THE DISTRIBUTION MANIFOLD IN THE CONSTRUCTION OF THE SOLAR WALL FOR THE CONDITIONS OF CIRCULATION
}

\author{
${ }^{1}$ Stepan SHAPOVAL, ${ }^{2}$ Vasyl ZHELYKH, ${ }^{3}$ Nadiia SPODYNIUK $*$ \\ ${ }^{4}$ Oleksandra DZERYN, ${ }^{5}$ Bogdan GULAI
}

\begin{abstract}
1,2,4,5 Heat, Gas Supply and Ventilation Department, Institute of Building and Environmental Engineering, Lviv Polytechnic National University, Stepan Bandera str, 12, Lviv-13, Ukraine e-mail: ${ }^{1}$ shapovalstepan@gmail.com, ${ }^{2}$ v_zhelykh@msn.com, ${ }^{4}$ oleksandra.dzeryn@gmail.com 508bogdan1986@gmail.com

${ }^{3}$ Metal Science and Heat Treatment Department, National Technical University of Ukraine 'Igor Sikorsky Kyiv' Polytechnic Institute, e-mail: nadijkaua44@gmail.com
\end{abstract}

Received 2 January 2018; accepted 22 January 2019

\begin{abstract}
The aim of the research was to explore the proposed solar installation, which consisting of a solar wall, storage tank, radiation sources and measuring equipment. The solar installation was tested in a circulating mode, which is an important point in energy conservation. Planning the installation of the collector heating system is still at the stage of building the house. Therefore, it remains relevant to replace the traditional boiler on the solar wall in quality of the solar collector, which will be used to heat water in the system and/or the pool completely free of charge. Proposed construction of the solar wall is effective for the solar heat supply system, at the same time the results of research confirm not only the efficiency of the system, but also allow for the design stage to take into account the practical efficiency of the system. Solar wall in circulation mode has a sufficiently effective coefficient for combined hot water supply or preheating of the heating medium of the heating system. The main theses of this work also would like to mark the affordability for the consumer, since the following design does not require a separate installation, and has the ability to mount in the existing wall
\end{abstract}

Keywords: Solar wall, Storage tank, Heat supply, Thermal power

\section{Introduction}

The sun is an inexhaustible and the most affordable source of energy, which nature gives for human. The most effective way of using solar energy is its absorption solar collectors. Installation of solar collector systems is the most valuable investment in the future [1].

\footnotetext{
${ }^{*}$ Corresponding Author
} 
From historical sources it is known that the year 1883 in the world is considered to be the beginning of the era of solar energy in electricity. This is a topical issue for Ukraine, because it is located on the territory with sufficient surface density of solar radiation.

In Ukraine the sector of solar electricity significantly began to develop in 2004, and the industry of heating since 2011. The slow development of solar systems has a number of causes, which are the main stages in the development of systems of solar heat supply for Ukraine [2].

The interest of engineers in solar energy is due to the fact that it is free energy, which also is not harmful to the environment and is effective in the use on all latitudes of the earth's surface. The presence of solar installations indicates on the high environmental awareness of the owner of the household.

It should also be noted that the reorganization of the technological structure of the industrial and residential sectors of Ukraine with the use of scientific and technical developments of solar heat supply systems will significantly balance the state of consumption of organic fossil fuels and increasing the share of consumption of renewable energy sources.

It is possible to use solar energy not only for heating but also for cooling buildings and structures. As a result, there will be a decrease in energy consumption [3].

\section{The aim of work}

The purpose of this work was to investigate the efficiency of solar walls in circulation mode.

\section{Previous studies}

Interestingly, in connection of increasing of abnormal natural phenomena on the planet Earth, scientists began to devote much more interest in energy conservation. As a result there have been published a lot of scientific and practical works respectively [4][9], which covers the issue of energy efficiency, etc. The formation of energy security of the state in the context of energy conservation is devoted to a number of works [4]. In particular, the prospects of replacing traditional fuel and energy resources with the use of alternative energy sources have been made in scientific works [4].

Most of the works argue that the use of alternative energy sources in the world, especially solar and wind energy will certainly be profit for the world [5].

American scientist John Ricardo Cole asserts that the world stands on the threshold of the 'Age of solar energy' [6].

Todays popularized a variety of designs of solar installations containing a range of protective coatings or heat insulation layers or even more innovative construction thermal conduction layer [7], [8], [9].

However, a flat Solar Collector (SC) remains popular. The flat collector - the most common type of solar collectors - reduces heat losses on the sides and from the back 
surface. Flat collectors are used for low temperature processes up to $80^{\circ} \mathrm{C}$. For higher temperatures it is better to use systems with solar hubs [10], [11].

\section{Experimental research}

For research there was designed an experimental installation, consisting of a solar wall, storage tank, radiation sources and measuring equipment.

Furthermore, it was necessary along with experiments carried out monitoring of factors that could cause errors in the measurements.

The intensity of the source radiation flux was measured by an actinometer LIOT-N. The solar radiation was measured on the vertical plane 5 (Fig. 1) at different angels of incidence of solar rays. At the same time the temperature of the outside air and its velocity was measured by a thermoelectric-anemometer TESTO 405 - V1. It was advisable to carry out temperature measurements: the heat carrier at the input and output of the solar wall, the temperature of heat carrier in the storage tank of system and the temperature of the surrounding environment [12], [13].

Changes of parameters and data collection were carried out manually. Processing of experimental data was carried out by using computer programs and the graphical and analytical method.

The solar installation was tested in a circulating mode, which is an important point in energy conservation. The diagram of the experimental installation of the solar wall in circulation mode is shown in Fig. 1.

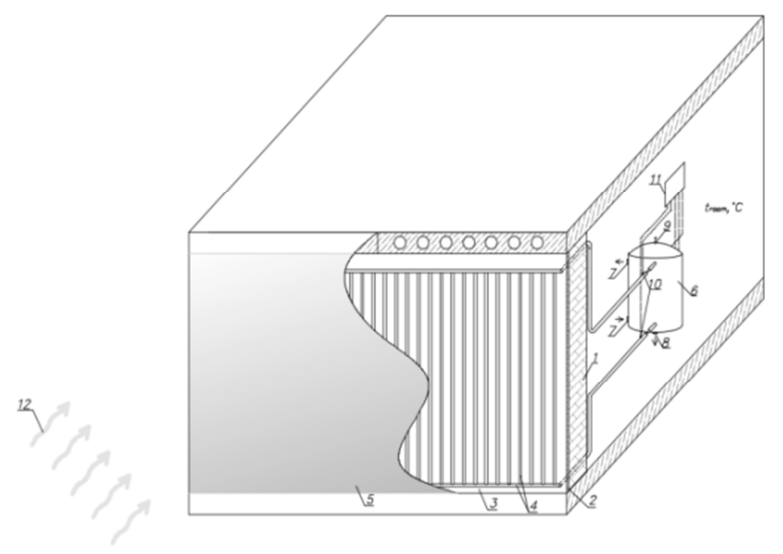

Fig. 1. The experimental setup: 1 - solar wall; 2 - thermal insulation layer;

3 - heat reflecting layer; 4 - distribution manifold; 5 - cover material; 6 - storage tank; 7 - pipes for selection and flow of heat carrier; 8 - the discharge pipe of the heat carrier; 9 - air outlet valve; 10 - thermometer; 11 - display; 12 - radiation source

This Solar Heat Supply System (SHSS) in the circulation mode can be used for seasonal water pre-heating for pools and showers, solar-fuel boiler-houses, for domestic purposes, etc. 
An important indicator of the parameters in the circulation mode was the change in the temperature of the heat carrier at the storage tank when also was changed the intensity of the solar energy [14], [15]. The temperature was important to lead to averaging, since a row of experimental studies were conducted, as well as the temperature in the tank of the battery was divided into three levels for better monitoring of the distribution of the heat carrier in the tank, which is also important for some average calculations (Fig. 2 and Fig. 3). The temperature of the heat carrier was measured by these parameters, namely $d=5 \mathrm{~mm} ; l=5 \mathrm{~mm}, \delta=1 \mathrm{~mm}$ and with the storage tank with volume of $0.015 \mathrm{~m}^{3}$.

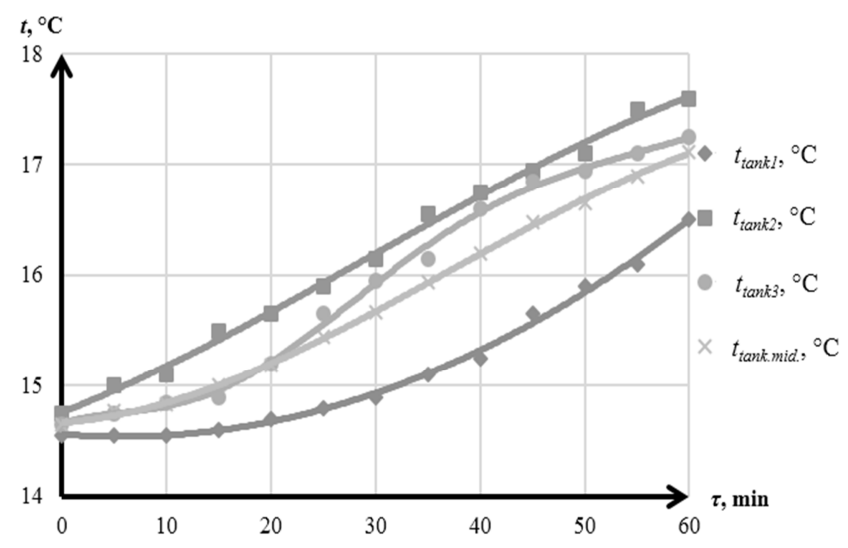

Fig. 2. Changing the temperature in the storage tank of the accumulator depending on the heating time in the mode of circulation at constant $G=0.2 \mathrm{1} / \mathrm{min} ; I=700 \mathrm{~W} / \mathrm{m}^{2}$, where $t_{\operatorname{tank1} \ldots .3},\left[{ }^{\circ} \mathrm{C}\right]$ is the temperature changes at the appropriate levels in storage tank; $t_{\text {tank.mid }},\left[{ }^{\circ} \mathrm{C}\right]$ is average temperature of storage tank

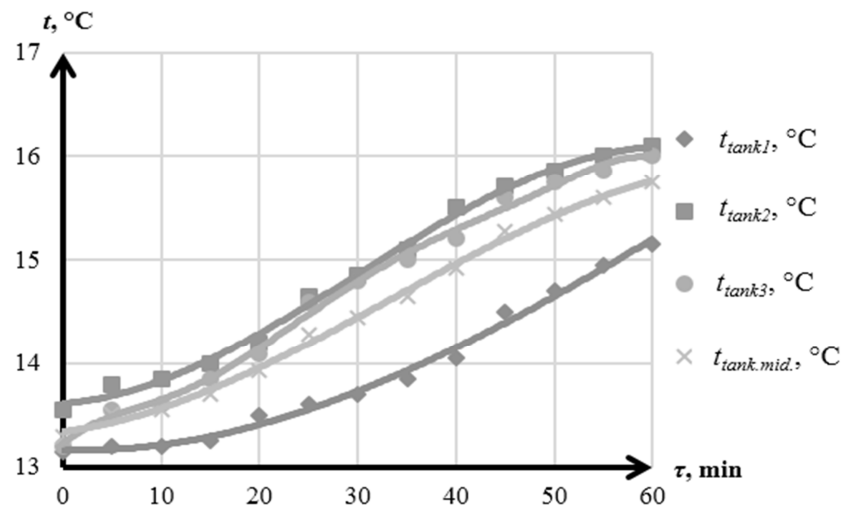

Fig. 3. Changing the temperature in the storage tank of the accumulator depending on the heating time in the mode of circulation at constant $G=0.21 / \mathrm{min} ; I=300 \mathrm{~W} / \mathrm{m}^{2}$, where $t_{\operatorname{tank1} \ldots 3},\left[{ }^{\circ} \mathrm{C}\right]$ is the temperature changes at the appropriate levels in storage tank; $t_{\text {tank.mid }},\left[{ }^{\circ} \mathrm{C}\right]$ is average temperature of storage tank 
For the maximum detection of the influence of factors on the response function was compiled a matrix of planning Full Factorial Experiment 54 (FFE 54) taking into account the effect of the interaction of factors. Since four factors are in the 5 levels, then 625 experiments should be done. In this regard, it is advisable to construct a Central Composite Rotatable Plan (CCRP) of the 2nd order, (see Table I).

One of the main tasks in the mode of circulation was investigation of the thermal power in the constructed SHSS under constant structural dimensions of the system $d=5$ $\mathrm{mm} ; l=5 \mathrm{~mm}, \delta=1 \mathrm{~mm}$, in particular, to investigate the instantaneous system parameters and with accumulation.

\section{Table I}

Matrix of experiment planning

\begin{tabular}{|l|l|l|l|l|l|l|}
\hline \multirow{2}{*}{$\begin{array}{l}\text { The name of } \\
\text { the factor }\end{array}$} & \multirow{2}{*}{ Coded } & \multicolumn{4}{|l|}{ The levels of factors } \\
\cline { 3 - 6 } & & -2 & -1 & 0 & 1 & 2 \\
\hline I & $x_{1}$ & 2 & 3 & 4 & 5 & 6 \\
II & $x_{2}$ & 10 & 30 & 50 & 70 & 90 \\
III & $x_{3}$ & 100 & 300 & 500 & 700 & 900 \\
IV & $x_{4}$ & 10 & 30 & 50 & 70 & 90 \\
\hline
\end{tabular}

I - speed of air flow, $v$, [m per sec]; II - direction of air flow, $a$, [ ${ }^{\circ}$ ]; III - intensity of the solar flow, $I$, [W per $\left.\mathrm{m}^{2}\right]$; IV - angle of incidence of solar rays, $b,\left[^{\circ}\right]$

The instantaneous specific thermal power $Q_{S H S S},\left[\mathrm{~J} / \mathrm{m}^{2}\right]$ of the SHSS is increasing to the middle of experiment time, which may be due to the heating of the system [16], [17]. The change in instantaneous specific thermal power for the following parameters ranged from $16-73 \mathrm{~J} / \mathrm{m}^{2}$ under a constant solar radiation of $700 \mathrm{~W} / \mathrm{m}^{2}$ (Fig. 4).

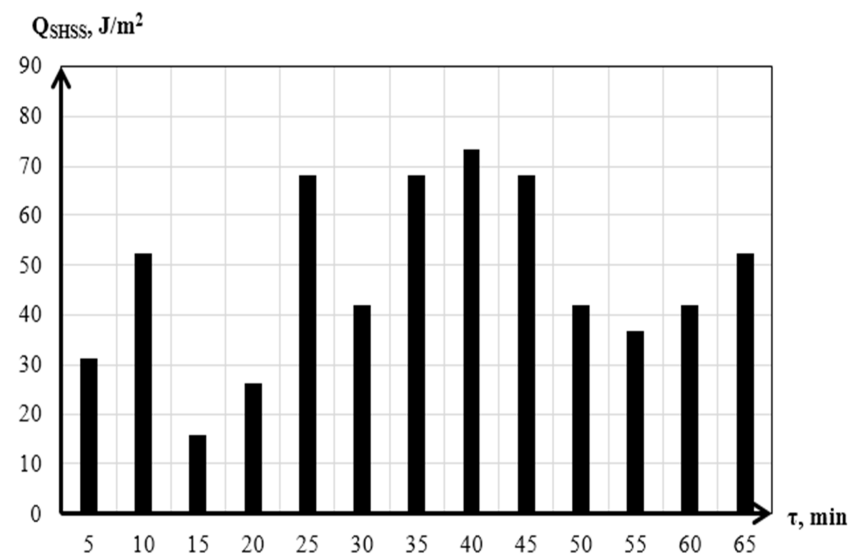

Fig. 4. Specific thermal power $Q_{S H S S},\left[\mathrm{~J} / \mathrm{m}^{2}\right]$ of the (SHSS) in the mode of circulation at constant $G=0.2 \mathrm{l} / \mathrm{min} ; I=700 \mathrm{~W} / \mathrm{m}^{2} ; V=0.015 \mathrm{~m}^{3} ; a=70^{\circ} ; b=30^{\circ} ; v=5 \mathrm{~m} / \mathrm{sec}$ 
Some of the results of the instantaneous specific thermal power with accumulation of thermal energy $Q_{S H S S}, \mathrm{~kJ} / \mathrm{m}^{2}$ under the smallest intensity of solar radiation and they are represented in graphic form (Fig. 5).

The main results of the experimental measurements changes the instantaneous specific thermal power of the solar wall with the distribution manifold absorber as it is shown in three-dimensional form in Fig. 6.

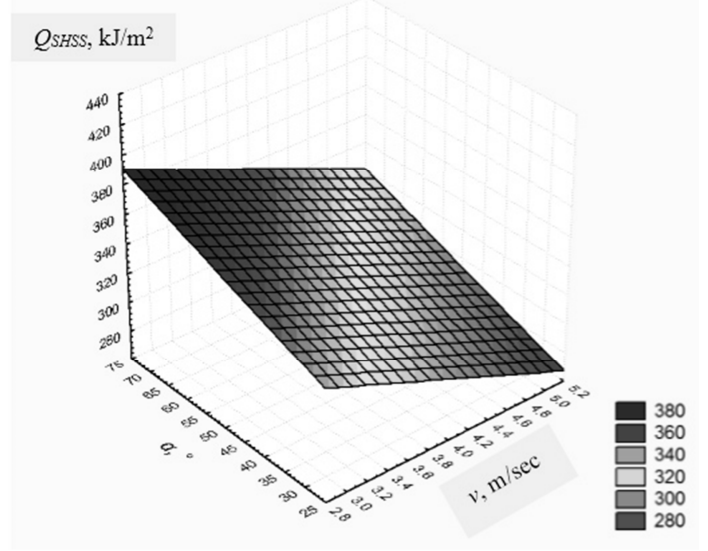

Fig. 5. Change of speed of air flow, direction of air flow and specific thermal power $Q_{S H S S},\left[\mathrm{~kJ} / \mathrm{m}^{2}\right]$ with accumulation in the SHSS in the mode of circulation at constant $G=0.2 \mathrm{l} / \mathrm{min} ; I=300 \mathrm{~W} / \mathrm{m}^{2} ; V=0.015 \mathrm{~m}^{3} ; b=30^{\circ}$

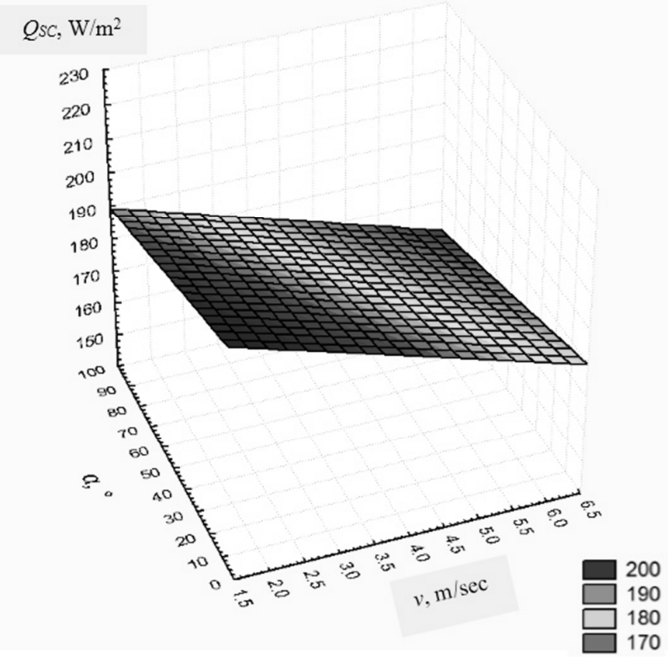

Fig. 6. Change of speed of air flow, direction of air flow and specific thermal power of the solar wall in quality of a SC with the distribution manifold $Q_{S C}, \mathrm{~W} / \mathrm{m}^{2}$ in the mode of circulation at constant $G=0.21 / \mathrm{min} ; I=500 \mathrm{~W} / \mathrm{m}^{2} ; V=0.015 \mathrm{~m}^{3} ; b=50^{\circ}$ 
An important point in the study of the solar wall was to consider the changes of the efficiency of the SHSS behind the solar collector, overall in the heart of collector and overall with accumulation in the storage tank in circulation mode, depending on the factors chosen by the authors. Also a similar solution will allow engineers to calculate foreseeable systems for practical use with assumptions of practical efficiency of the systems, depending on the speed of air flow, direction of air flow, intensity of the solar flow, angle of incidence of solar rays.

The maximum achieved efficiency of the system of heat solar supply behind the SC was $\approx 65 \%$ and shown in Fig 7 .

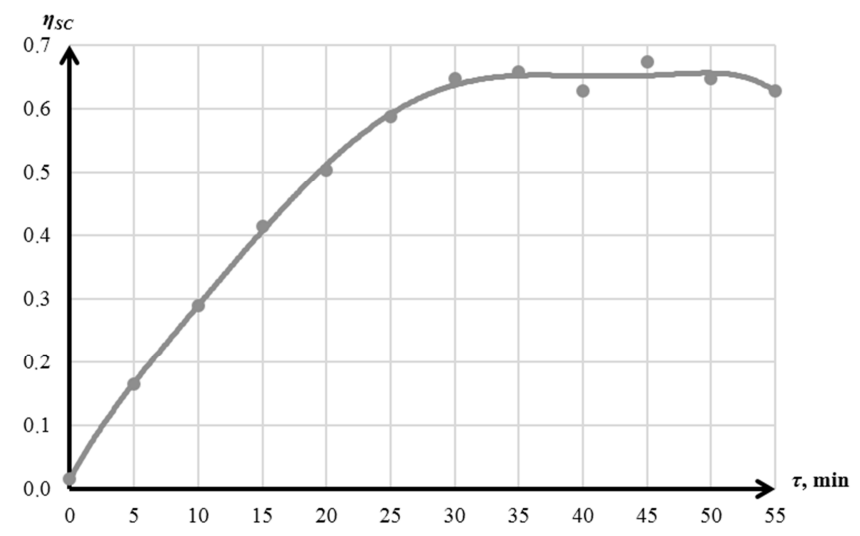

Fig. 7. Change of efficiency of the system of heat solar supply behind the SC, $\eta_{S C}$, in the mode of circulation at constant $G=0.21 / \mathrm{min} ; I=700 \mathrm{~W} / \mathrm{m}^{2} ; V=0.015 \mathrm{~m}^{3} ; a=30^{\circ} ; b=70^{\circ} ; v=3 \mathrm{~m} / \mathrm{sec}$

One of the interesting results of the developed system was the achievement of $58 \%$ efficiency in overall by the SHSS under intensity of solar radiation $500 \mathrm{~W} / \mathrm{m}^{2}$ (Fig. 8).

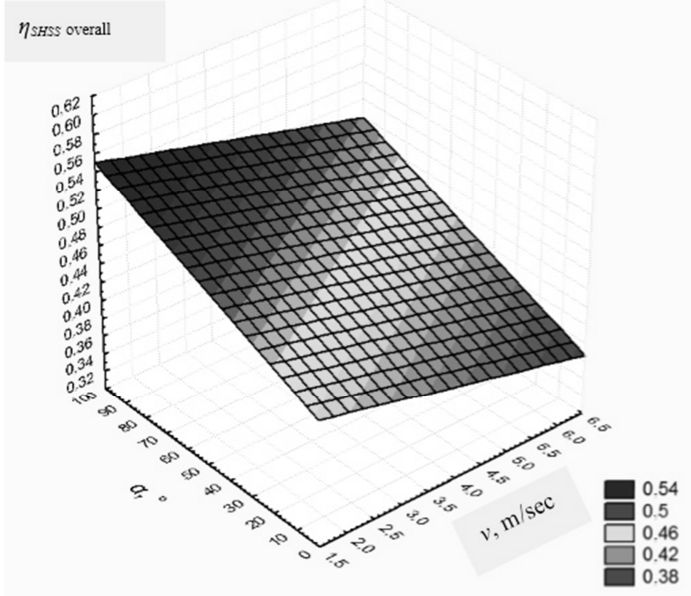

Fig. 8. Change of overall efficiency in the heart of collector of the system of heat solar supply $\eta_{S H S S \text { overall }}$, in the mode of circulation at constant $G=0.21 / \mathrm{min} ; I=500 \mathrm{~W} / \mathrm{m}^{2} ; V=0.015 \mathrm{~m}^{3} ; b=50^{\circ}$ 
As it can be seen from the graph in Fig. 9 the overall efficiency of the solar wall with the accumulation of thermal energy in the storage tank reaches a value of $38 \%$, which is an important moment in maintaining energy conservation.

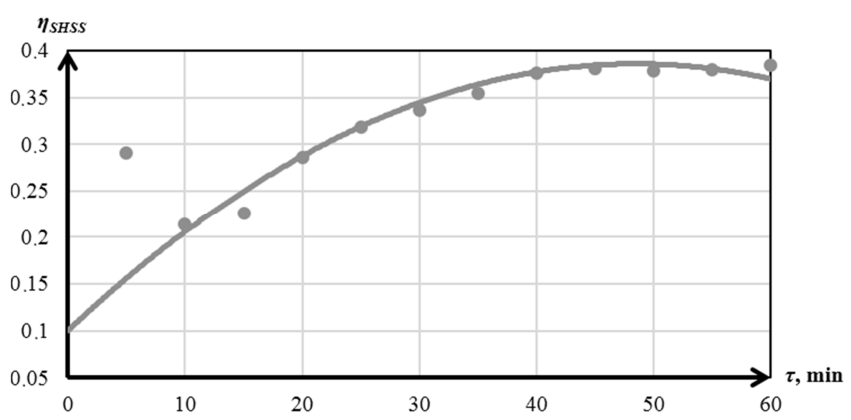

Fig. 9. Change of overall efficiency with accumulation in the storage tank $\eta_{S H S S}$, in the circulation mode at constant $G=0.21 / \mathrm{min} ; I=900 \mathrm{~W} / \mathrm{m}^{2} ; V=0.015 \mathrm{~m}^{3} ; a=50^{\circ} ; b=50^{\circ} ; v=4 \mathrm{~m} / \mathrm{sec}$

Worth paying attention to the summarized results of researches with the intensity of solar radiation $300 \mathrm{~W} / \mathrm{m}^{2}$, which are given in Table II and Table III since they were investigated with the minimum intensity solar radiation chosen by the authors.

For example, under the intensity of solar radiation by $300 \mathrm{~W} / \mathrm{m}^{2}$ and the air flow direction of only $30^{\circ}$, the efficiency of the system of heat solar supply behind the SC was $55 \%$ and it was already reached within 20 minutes from the beginning of the experiment.

As the result of the processing of experimental data was obtained the regression equation (1) of the efficiency of SHSS behind the SC $\eta_{S C}$ has the form:

$$
\begin{aligned}
y= & -0.006 x_{1}-0.019 x_{2}-0.018 x_{3}+0.025 x_{4}-0.024 x_{1} x_{2} \\
& +0.014 x_{1} x_{3}-0.009 x_{1} x_{4}+0.008 x_{2} x_{3}+0.002 x_{2} x_{4} \\
& -0.017 x_{3} x_{4}+0.139 x_{1}^{2}+0.157 x_{2}^{2}+0.127 x_{3}^{2}+0.152 x_{4}^{2} .
\end{aligned}
$$

On the basis of the analysis of regression coefficients it can be asserted:

- the factor $x_{4}$ (angle of incidence of solar rays, $\beta,^{\circ}$ ) has a significant influence on the behavior of the response function and factors $x_{3}$ (intensity of the solar flow, $I, \mathrm{~W} / \mathrm{m}^{2}$, direction of air flow, a, ${ }^{\circ}$, and speed of air flow, $v, \mathrm{~m} / \mathrm{sec}$ affect not so much on the efficiency of the SC $\eta_{S C}$;

- numerical increase of the square number of all previously selected factors leads to growth of system efficiency of heat solar supply behind the solar collector;

- Also it would be perfect to note the intermediate results of the research received in the process of work. Intermediate results of the study show the priority areas of the system, and this could be important scientific or practical tasks. 
Table II

Dynamics of change of thermal characteristics of combined solar wall with structural features

$d=5 \mathrm{~mm} ; l=5 \mathrm{~mm} ; \delta=1 \mathrm{~mm}$ in the mode of circulation at constant $G=0.21 / \mathrm{min} ; I=300 \mathrm{~W} / \mathrm{m}^{2}$; $V=0.015 \mathrm{~m}^{3} ; b=70^{\circ}$

\begin{tabular}{|c|c|c|c|c|c|}
\hline № & $x_{1}$ & $x_{2}$ & $a$ & $b$ & $c$ \\
\hline 1 & 3 & 30 & 176 & 64 & 404 \\
2 & 5 & 30 & 155 & 67 & 402 \\
3 & 3 & 70 & 153 & 55 & 326 \\
4 & 5 & 70 & 131 & 61 & 369 \\
\hline
\end{tabular}

where $a$ is the specific thermal power of the solar wall in quality of a solar collector with the distribution manifold $Q_{S C}, \mathrm{~W} / \mathrm{m}^{2} ; b$ is the specific thermal power $Q_{S H S S}, \mathrm{~J} / \mathrm{m}^{2}$ of the SHSS; $c$ is the specific thermal power $Q_{S H S S}, \mathrm{~kJ} / \mathrm{m}^{2}$ with accumulation in the SHSS.

\section{Table III}

Dynamics of change of efficiency in combined solar wall with structural features $d=5 \mathrm{~mm} ; l=5 \mathrm{~mm} ; \delta=1 \mathrm{~mm}$ in the mode of circulation at constant $G=0.21 / \mathrm{min} ; I=300 \mathrm{~W} / \mathrm{m}^{2}$; $V=0.015 \mathrm{~m}^{3} ; b=70^{\circ}$

\begin{tabular}{|c|c|c|c|c|c|}
\hline № & $x_{1}$ & $x_{2}$ & $d$ & $f$ & $g$ \\
\hline 1 & 3 & 30 & 0.59 & 0.71 & 0.66 \\
2 & 5 & 30 & 0.55 & 0.75 & 0.63 \\
3 & 3 & 70 & 0.51 & 0.62 & 0.48 \\
4 & 5 & 70 & 0.44 & 0.68 & 0.63 \\
\hline
\end{tabular}

where $d$ is the efficiency of the system of heat solar supply behind the SC $\eta_{S C} ; f$ is the overall efficiency in the heart of collector of the system of heat solar supply $\eta_{S H S S}$ overall $; g$ is the overall efficiency with accumulation in the storage tank $\eta_{S H S S}$.

For example, the change in the heat loss coefficient, $K_{S W}$ (solar wall), $\mathrm{W} /\left(\mathrm{m}^{2} \cdot \mathrm{K}\right)$ is shown in Fig. 10.

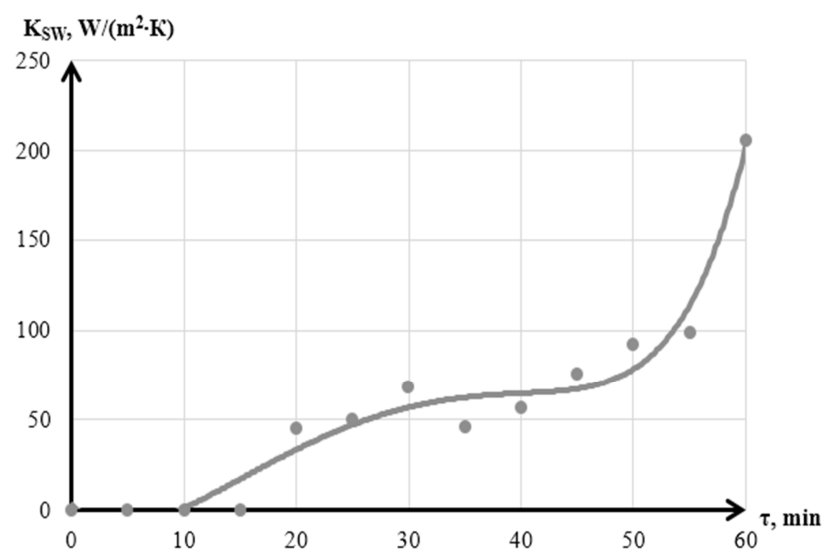

Fig. 10. Changing the heat loss factor of the solar wall in quality of a SC with the distribution manifold in the circulation mode at constant $G=0.21 / \mathrm{min} ; I=700 \mathrm{~W} / \mathrm{m}^{2} ; V=0.015 \mathrm{~m}^{3}$; $a=70^{\circ} ; b=70^{\circ} ; v=5 \mathrm{~m} / \mathrm{sec}$ 
Comparing the results of the heat loss coefficient for $700 \mathrm{~W} / \mathrm{m}^{2}$ and $300 \mathrm{~W} / \mathrm{m}^{2}$, it is found that they differ by more than 10 times for the selected coordinate points (Fig. 11).

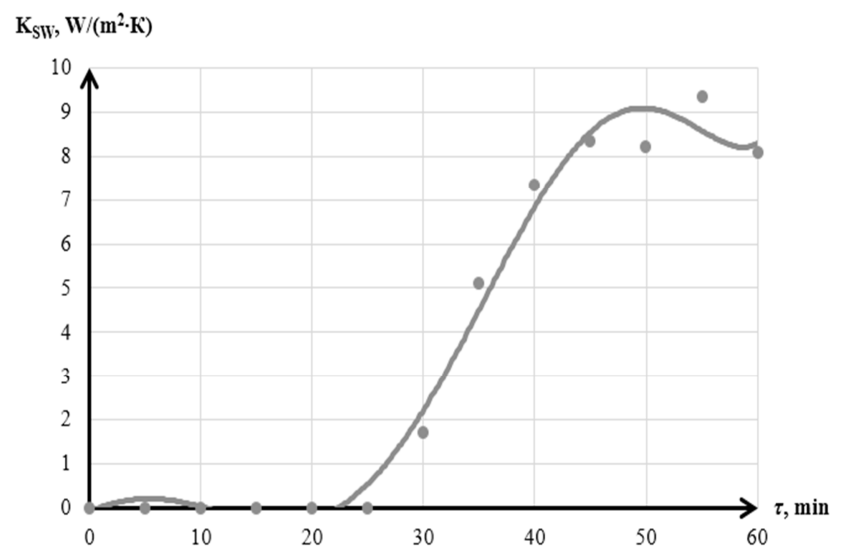

Fig. 11. Changing the heat loss factor of the solar wall in quality of a SC with the distribution manifold in the circulation mode at constant $G=0.21 / \mathrm{min} ; I=300 \mathrm{~W} / \mathrm{m}^{2} ; V=0.015 \mathrm{~m}^{3}$; $a=70^{\circ} ; b=70^{\circ} ; v=5 \mathrm{~m} / \mathrm{sec}$

In addition, the increase of $\Delta$ temperature in the system and of the environment was determined. It was found that the temperature of the environment due to the good thermal insulation of the system did not significantly affect however, completely excluded this factor was not possible (Fig. 12 and Fig. 13).

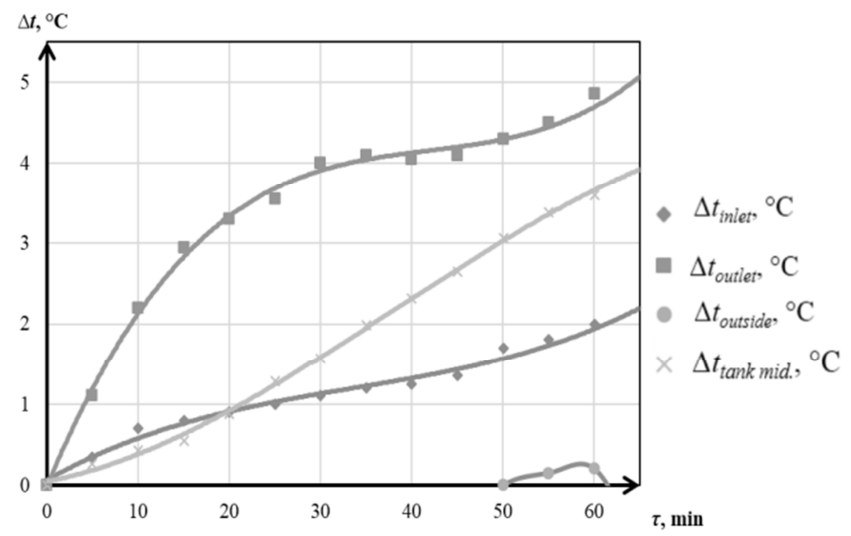

Fig. 12. The changing of $\Delta$ temperature of the heat carrier due to the research of solar walls with the distribution manifold in the circulation mode at the entrance $\Delta t_{\text {inlet }},{ }^{\circ} \mathrm{C}$, outlet $\Delta t_{\text {outlet }},{ }^{\circ} \mathrm{C}$ the solar collector, the ambient temperature $\Delta t_{\text {outside }},{ }^{\circ} \mathrm{C}$ and the average temperature of storage tank $\Delta t_{\text {tank.mid }},{ }^{\circ} \mathrm{C}$ during the experiment at constant $G=0.2 \mathrm{l} / \mathrm{min} ; I=500 \mathrm{~W} / \mathrm{m}^{2} ; V=0.015 \mathrm{~m}^{3}$; $a=50^{\circ} ; b=90^{\circ} ; v=4 \mathrm{~m} / \mathrm{sec}$ 
The temperature was increased around $7{ }^{\circ} \mathrm{C}$ during the experiment. Worth mentioning is the steady increase in temperature at the outlet from the solar wall and in the storage tank, which with a certain extent shows the efficiency of the system.

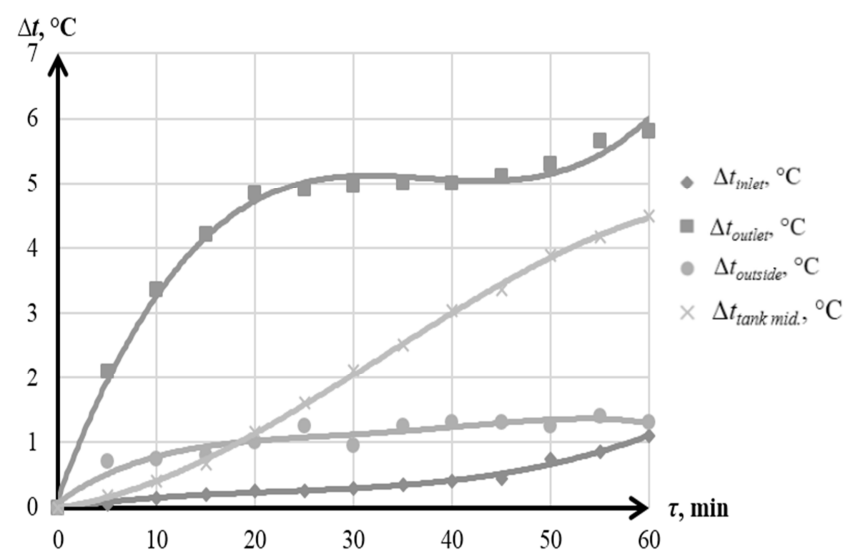

Fig. 13. The changing of $\Delta$ temperature of the heat carrier due to the research of solar walls with the distribution manifold in the circulation mode at the entrance $\Delta t_{\text {inlet }},{ }^{\circ} \mathrm{C}$, outlet $\Delta t_{\text {outlet }},{ }^{\circ} \mathrm{C}$ the solar collector, the ambient temperature $\Delta t_{\text {outside }},{ }^{\circ} \mathrm{C}$ and the average temperature of storage tank $\Delta t_{\text {tank.mid }},{ }^{\circ} \mathrm{C}$ during the experiment at constant $G=0.21 / \mathrm{min} ; I=700 \mathrm{~W} / \mathrm{m}^{2} ; V=0.015 \mathrm{~m}^{3}$; $a=30^{\circ} ; b=70^{\circ} ; v=5 \mathrm{~m} / \mathrm{sec}$

\section{Conclusion}

Planning the installation of the collector heating system is still at the stage of building the house. Therefore, it remains relevant to replace the traditional boiler on the solar wall in quality of the solar collector, which will be used to heat water in the system and/or the pool completely free of charge.

This system, above all, is recommended for heating water during the period of the highest solar activity, that is, in the summer. Using solar wall, it is possible to significantly reduce the costs that are spent for heating water.

Summing up the above data, it can be argued that the proposed construction of the solar wall is effective for the SHSS. And the results of research confirm not only the efficiency of the system, but also allow for the design stage to take into account the practical efficiency of the system.

In addition, the solar wall in circulation mode has a sufficiently effective coefficient for combined hot water supply or preheating of the heating medium of the heating system. The main theses of this work also would like to mark the affordability for the consumer, since the following design does not require a separate installation, and has the ability to mount in the existing wall. For instance, at an intensity of radiation of $700 \mathrm{~W} / \mathrm{m}^{2}$ in the mode of circulation, the efficiency of the system of heat solar supply behind the SC $\eta_{S C}$ reached $65 \%$, and on the overall efficiency with accumulation in the storage tank $\eta_{\text {SHSS }}$ reached around $38 \%$. 


\section{References}

[1] Zhelykh V., Spodyniuk N., Shepitchak V., Kapalo P. The study of temperature regime of infrared heating systems in industrial premises, Fizyka Budowli w Teorii i Praktyce, Vol. 8, No. 3, 2016, pp. 43-46.

[2] Petruk V., Kotsiubynska S., Matsiuk D. Energy potential of alternative energy in Ukraine, (in Ukrainian) Vinnitsa Politechnic Institute Bulletin, Vol. 4, 2007, pp. 90-93.

[3] Košičanová D., Fedorčák P. Reducing energy consumption with using ventilation and solar cooling, school building's case study, Pollack Periodica, Vol. 6, No. 2, 2011, pp. 131-138.

[4] Kravchuk V., Kaplun V. On the issue of creating a combined power supply system for energy-efficient (passive) buildings (in Ukrainian), Tekhnika i tekhnolohiyi APK, 2012, pp. 9-14.

[5] Bryuner K., Buxmajyer Yu., Flyush Yu., Myuster-Slavych B. The use of solar thermal energy in industry, (in Ukrainian) Gleisdorf, 2015.

[6] Age of solar energy, (in Ukainian) 2016, smarteco.biz.ua, (last visited 24 April 2017).

[7] Patent US6513518 B1, Solar cell panel and solar energy collecting device, S. Girerd, No. 09/674030, 2003.

[8] Patent US4201193, Solar energy absorbing roof, M. Ronc, No. 05/887,938, 1980.

[9] Pluta Z. Solar energy installations, (in Polish) Oficyna Wydawnicza Politechniki Warszawskiej, 2007.

[10] Zhelykh V., Shapoval S., Venhryn I. The potential of radiant energy and its use for lowtemperature solar collectors, (in Ukrainian) Zakhyst navkolyshnoho seredovyshcha. Enerhooshchadnist. Zbalansovane pryrodokorystuvannya, No. 3, 2014.

[11] Zhelykh V., Kozak Ch., Savchenko O. Using of thermosiphon solar collector in an air heating system of passive house, Pollack Periodica, Vol. 11, No. 2, 2016, pp. 125-133.

[12] Riegger C. Transpired solar collector walls: Use solar, save green, Interface, 2008, pp. 5-8.

[13] Gregoire R. G. Understanding solar food dryers, Volunteers in Technical Assistance, 1984.

[14] Śliwowski L. Microclimate of interiors and thermal comfort of people in rooms, (in Polish) Oficyna Wydawnictwa Politechniki Wrocławskiej, 2000.

[15] Basok B. I., Bozhko I. K., Byelyayeva T. H. Polyvalent heat system for the experimental passive type building $\left(300 \mathrm{~m}^{2}\right)$ based on the use of renewable and alternative energy sources, (in Ukrainian) Nauka ta innovatsiyi, Kiev, No. 6, Vol. 10, 2014, pp. 34-51.

[16] Solar and heat pump hot water systems, Plumber Training Handbook, Commonwealth of Australia, 2010.

[17] Talamon A. Global renewable energy trends and Hungary, (in Ukrainian) Journal of Lviv Politechnic National University, Theory and Practice of Building, No. 781, 2014, pp. 230233. 